\title{
Identification of an Essential Region for Translocation of Clostridium difficile Toxin B
}

\author{
Shuyi Chen ${ }^{1}$, Haiying Wang ${ }^{1}$, Huawei Gu ${ }^{1}$, Chunli Sun ${ }^{1}$, Shan Li ${ }^{1}$, Hanping Feng ${ }^{2}$ \\ and Jufang Wang ${ }^{1, *}$ \\ 1 School of Bioscience and Bioengineering, South China University of Technology, Guangzhou 510006, China; \\ shuyichan@foxmail.com (S.C.); yingzi224926@163.com (H.W.); guhuawei1990@163.com (H.G.); \\ chunlis@163.com (C.S.); lishan@scut.edu.cn (S.L.) \\ 2 Department of Microbial Pathogenesis, University of Maryland Dental School, Baltimore, MD 21201, USA; \\ hfeng@umaryland.edu \\ * Correspondence: jufwang@scut.edu.cn; Tel.: +86-20-3938-0656
}

Academic Editor: Harald Genth

Received: 19 July 2016; Accepted: 8 August 2016; Published: 15 August 2016

\begin{abstract}
Clostridium difficile toxin A (TcdA) and toxin B (TcdB) are the major virulence factors involved in C. difficile-associated diarrhea and pseudomembranous colitis. TcdA and TcdB both contain at least four distinct domains: the glucosyltransferase domain, cysteine protease domain, receptor binding domain, and translocation domain. Few studies have investigated the translocation domain and its mechanism of action. Recently, it was demonstrated that a segment of 97 amino acids (AA 1756-1852, designated D97) within the translocation domain of TcdB is essential for the in vitro and in vivo toxicity of TcdB. However, the mechanism by which D97 regulates the action of TcdB in host cells and the important amino acids within this region are unknown. In this study, we discovered that a smaller fragment, amino acids 1756-1780, located in the $N$-terminus of the D97 fragment, is essential for translocation of the effector glucosyltransferase domain into the host cytosol. A sequence of 25AA within D97 is predicted to form an alpha helical structure and is the critical part of D97. The deletion mutant $\operatorname{TcdB}_{\Delta 1756-1780}$ showed similar glucosyltransferase and cysteine protease activity, cellular binding, and pore formation to wild type $\mathrm{TcdB}$, but it failed to induce the glucosylation of Rho GTPase Rac1 of host cells. Moreover, we found that $\mathrm{TcdB}_{\Delta 1756-1780}$ was rapidly degraded in the endosome of target cells, and therefore its intact glucosyltransferase domain was unable to translocate efficiently into host cytosol. Our finding provides an insight into the molecular mechanisms of action of TcdB in the intoxication of host cells.
\end{abstract}

Keywords: Clostridium difficile; toxin; translocation; endocytosis; conformational change

\section{Introduction}

Clostridium difficile is the major cause of antibiotic-associated diarrhea and pseudomembranous colitis worldwide. Two exotoxins, toxin A (TcdA) and toxin B (TcdB), are the major virulence factors involved in C. difficile infection (CDI) [1,2], and both belong to the family of clostridial glucosylating toxins. The toxins are multi-domain proteins containing at least four functional domains [3]. The $\mathrm{N}$-terminus of the toxin harbors the glucosyltransferase domain (GTD) that inactivates host Rho GTPases by glucosylation [4,5] and a cysteine protease domain (CPD) responsible for autoprocessing [6-8]. The C-terminus, consisting of combined repetitive oligopeptides (CROP), is predicted to be a receptor binding domain (RBD) $[9,10]$. The receptor for TcdB has been identified recently [11,12], but additional receptors may exist [13,14]. A large region between the CPD and RBD is thought to be the translocation domain (TD) which is important for delivery of $\mathrm{N}$-terminal enzymatic domains into the host cytosol via pore formation [15-19]. 
The molecular mode of action of the toxins is not completely understood, but it is widely accepted that the toxins bind to cell surface receptors via the RBD, and then enter the cells through endocytosis to reach endosomal compartments, in which the toxins undergo conformational change [18] and perform pore formation $[15,16]$ and eventually deliver the GTD across the endosomal membrane into the cytosol [20]. However, until now the structure of the TD and the molecular mechanism of toxin translocation have not been clarified. In recent years, much work has been done to explore the structure-function relationship of the translocation domain. In 1992, Von Eichel-Streiber et al. [10] found a hydrophobic area (amino acids 956-1128) which is involved in the membrane insertion of TcdB. Qa'Dan M. et al. [18] reported in 2000 that the low pH of early endosomes induces conformational changes of $\mathrm{TcdB}$, resulting in exposure of the hydrophobic area and membrane insertion. Torsten Giesemann et al. [21] showed in 2006 that TcdA induces pore formation in an acidic environment in colonic cells that depends on the presence of cholesterol. In 2011, Selda Genisyuerek and coworkers [16] found a region between amino acids 830-990 that is essential for pore formation of TcdB. Last year, Zhifen Zhang and coworkers [22] uncovered the highly sensitive residues located between amino acids 1035-1107 that are important for TcdB pore formation and transloction.

Recently, it was demonstrated that the D97 fragment is essential for the toxicity of TcdB [23]. Deletion of the D97 fragment does not influence the toxin's glucosyltransferase, cysteine protease activity, and endocytosis, but leads to failure in delivery of the GTD into host cytosol. It was hypothesized that the D97 fragment is essential for translocation of TcdB because, after its deletion, toxin molecules were trapped in the endosome.

This study aimed to find the critical structure in the D97 fragment and provide insights into its function. The region of AA 1756-1780 within the D97 fragment was determined to be essential for the translocation of TcdB.

\section{Results}

\subsection{Prediction of the Secondary Structure of the D97 Segment}

To gain insight into the structure-function relationship of TcdB, the secondary structure of the D97 segment was predicted by the algorithms GOR4, SIMPA96, and Chou-Fasman (ProtScal), which showed that the region of AA 1756-1780 of TcdB putatively formed an alpha-helical structure (Figure 1). There is no obvious alpha helical structure formation within the region of AA 1781-1851 according to the predictions. Therefore, we hypothesized that the AA 1756-1780 region of D97 is important. Therefore, 25AA (1756-1780) were deleted to construct the deletion mutant $\operatorname{TcdB}_{\triangle 1756-1780}$ (Figure 1). The deletion mutant $\mathrm{TcdB}_{\triangle 1827-1851}$ (Figure 1), with deletion of a different 25AA, 1827-1851, located in the $C$-terminus of D97, served as the control in the following experiments. The deletion mutants were expressed with $\mathrm{His}_{6}$-tags at the $C$-terminal in a B. megaterium expression system and purified by $\mathrm{Ni}^{2+}$ affinity chromatography.

To investigate whether the deletion causes improper folding of the proteins, we performed CD spectral analysis and estimated elements of the secondary structure of the toxins on the basis of the CONTIN algorithm. This showed that the mutant toxins maintained a similar secondary structure to $\mathrm{TcdB}_{\mathrm{fl}}$ (Table 1). The decrease in the alpha helical structure in the composition of $\mathrm{TcdB}_{\Delta 1756-1780}$ may be due to the deletion of AA 1756-1780. 


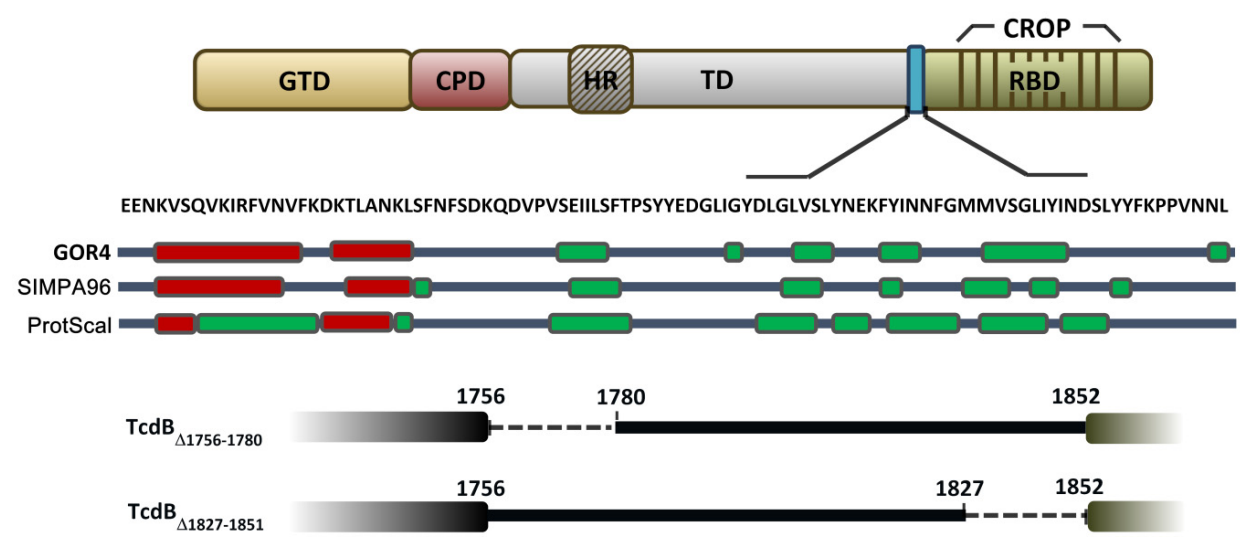

Figure 1. Structural diagram of $\mathrm{TcdB}_{\mathrm{fl}}, \mathrm{TcdB}_{\Delta 1756-1780}$, and $\mathrm{TcdB}_{\Delta 1827-1851}$ showing the domain structure of TcdB and the alpha helix, which is located in AA 1756-1780. GTD harbors glucosyltransferase activity. CPD can induce autocleavage of the toxin in the presence of $\mathrm{InsP}_{6}$. TD is responsible for GTD domain delivery. RBD is involved in cellular binding and endocytosis. The secondary structure of D97 was predicted using three algorithms (GOR4, SIMPA96, Chou-Fasman (ProtScal)). Alpha-helical and beta-sheet structures are presented as red and green boxes, respectively. The mutant toxins $\mathrm{TcdB}_{\triangle 1756-1780}$ and $\mathrm{TcdB}_{\triangle 1827-1851}$ with AA 1756-1780 and 1827-1851 deleted, respectively, are shown in the figure. Abbreviations: GTD, glucosytransferase domain; CPD, cysteine protease domain; TD, translocation domain; $\mathrm{HR}$, hydrophobic region within the translocation domain; RBD, receptor binding domain; D97, the region AA 1827-1851 of TcdB.

Table 1. Summary of secondary structure elements calculated from CD data.

\begin{tabular}{ccccc}
\hline Protein & A-helix (\%) & $\beta$-sheet (\%) & Random Coil (\%) & Total (\%) \\
\hline $\mathrm{rTcdB}_{\mathrm{fl}}$ & 6.5 & 52.6 & 40.8 & 99 \\
$\mathrm{TcdB}_{\Delta 1756-1780}$ & 5.8 & 53.5 & 40.9 & 100.2 \\
$\mathrm{TcdB}_{\Delta 1827-1851}$ & 6.1 & 53.1 & 40.8 & 100 \\
\hline
\end{tabular}

\subsection{Cytopathic and Cytotoxic Effects of $T c d B_{\Delta 1756-1780}$}

The cytopathic effects of $\mathrm{TcdB}_{\mathrm{fl}}, \mathrm{TcdB}_{\Delta 1756-1780}$, and $\mathrm{TcdB}_{\Delta 1827-1851}$ on CT26 and Vero cell lines were compared using a cell rounding experiment. As shown in Figure $2 \mathrm{~A}$, both $\mathrm{TcdB}_{\mathrm{fl}}$ and $\mathrm{TcdB}_{\triangle 1827-1851}$ caused $100 \%$ cell rounding at a concentration of $1 \mathrm{pg} / \mathrm{mL}$, while no obvious cell rounding was observed after treatment with $1 \mu \mathrm{g} / \mathrm{mL} \mathrm{TcdB}_{\Delta 1756-1780}$ for $24 \mathrm{~h}$. Furthermore, the result of the MTT assay indicated that the cytotoxic activity of $\mathrm{TcdB}_{\Delta 1756-1780}$ was decreased by about 6-7 logs compared with $\mathrm{TcdB}_{\mathrm{fl}}$ and $\mathrm{TcdB}_{\Delta 1827-1851}$ (Figure $2 \mathrm{~B}$ ). Finally, the in vivo toxicity of the toxins was examined by challenging BALB / $\mathrm{C}$ mice, and the survival of the mice was observed (Figure 2C). Mice challenged with $\operatorname{TcdB}_{\mathrm{fl}}(100 \mathrm{ng} / \mathrm{mouse})$ died within $12 \mathrm{~h}$, while mice challenged with $\operatorname{TcdB}_{\Delta 1827-1851}(100 \mathrm{ng} / \mathrm{mouse})$ died within $72 \mathrm{~h}$. By contrast, mice challenged with $\operatorname{TcdB}_{\Delta 1756-1780}(100 \mu \mathrm{g} /$ mouse), a concentration 1000-fold higher than that of $\mathrm{TcdB}_{\mathrm{fl}}$ and $\mathrm{TcdB}_{\Delta 1827-1851}$, showed no signs of disease and survived until the end of observation ( $96 \mathrm{~h}$ ). These results demonstrated that the alpha-helix located at AA 1756-1780 is the critical part of the D97 segment and is essential for the toxicity of TcdB. 
A.
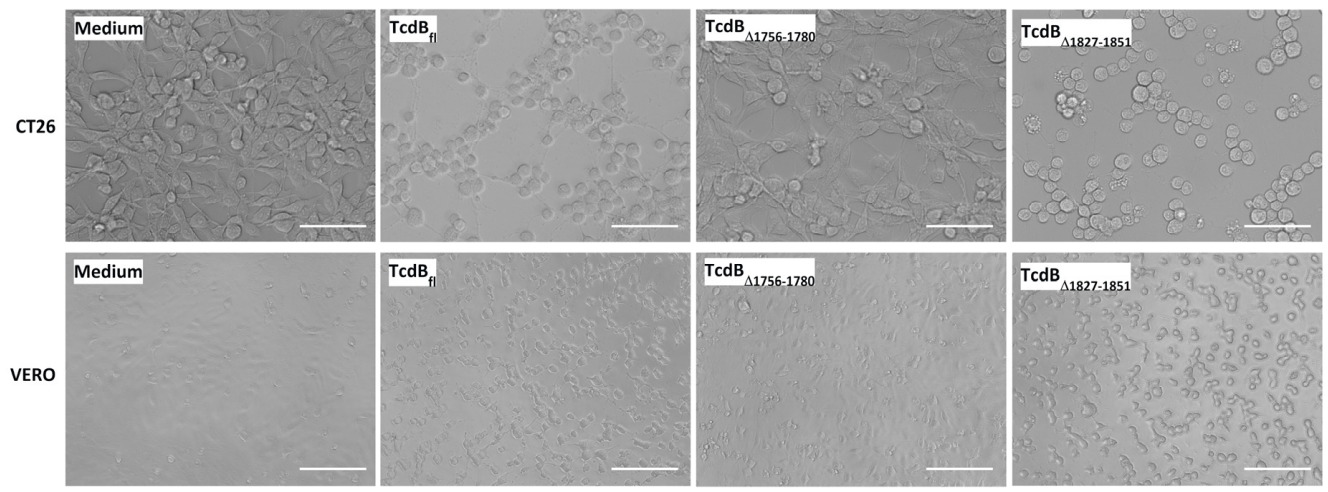

B.

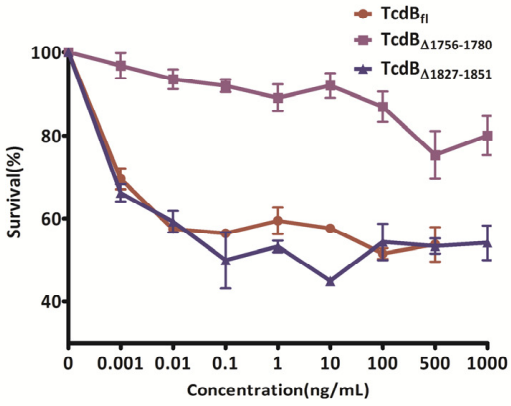

C.

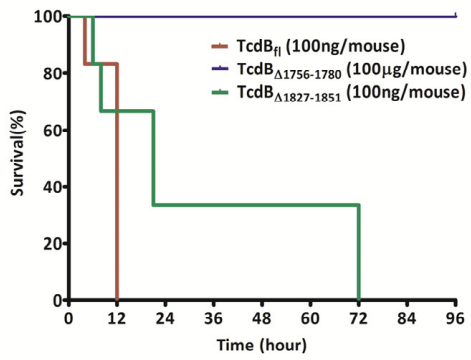

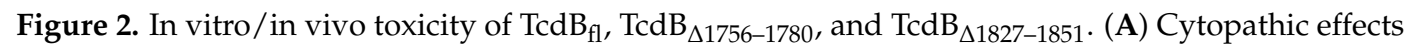

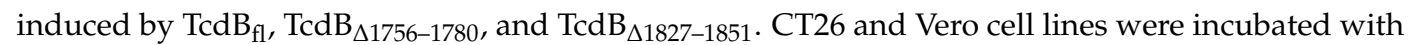
$\operatorname{TcdB}_{\mathrm{fl}}(1 \mathrm{pg} / \mathrm{mL}), \mathrm{TcdB}_{\Delta 1756-1780}(1 \mu \mathrm{g} / \mathrm{mL})$, and $\operatorname{TcdB}_{\Delta 1827-1851}(1 \mathrm{pg} / \mathrm{mL})$ for $24 \mathrm{~h}$ before microscopic analysis of cell morphology, scale bar $=50 \mu \mathrm{m}$; (B) Comparison of cytotoxicity of $\mathrm{TcdB}_{\Delta 1756-1780}$ and $\mathrm{TcdB}_{\Delta 1827-1851}$ with $\mathrm{TcdB}_{\mathrm{fl}}$. The CT26 cell line was incubated with the indicated concentrations of toxins for $72 \mathrm{~h}$ and the viability of the cells was measured by MTT assay. Cells without exposure to

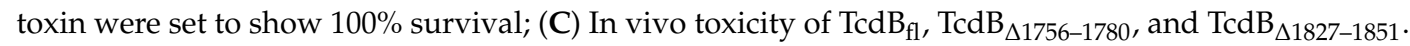
Groups of mice $(n=6)$ were injected intraperitoneally with $\mathrm{TcdB}_{\mathrm{fl}}(100 \mathrm{ng} / \mathrm{mouse}), \mathrm{TcdB}_{\Delta 1756-1780}$ (100 $\mu \mathrm{g} /$ mouse), or $\mathrm{TcdB}_{\Delta 1827-1851}$ (100 ng/mouse). The survival of the mice was monitored for $96 \mathrm{~h}$.

\subsection{Analysis of Cysteine Protease, Glucosyltransferase Activity, and Cellular Binding of TcdB $\Delta 1756-1780$}

To determine whether the deletion of AA 1756-1780 influenced the structure and function of CPD, GTD, and RBD, their cysteine protease activity, glucosyltransferase activity, and cellular binding were examined. Autoprocessing by the CPD was tested by an in vitro autocleavage assay. As shown in Figure $3 \mathrm{~A}, \mathrm{~B}$, both $\mathrm{TcdB}_{\Delta 1756-1780}$ and $\mathrm{TcdB}_{\mathrm{fl}}$ successfully induced autocleavage, releasing a $63 \mathrm{kD}$ fragment containing GTD, in the presence of $10 \mu \mathrm{M}$ InsP $_{6}$. Furthermore, the concentration dependence of InsP $\mathrm{P}_{6}$ and the time course of the cleavage reaction of $\mathrm{TcdB}_{\Delta 1756-1780}$ were investigated. This showed that $\operatorname{TcdB}_{\Delta 1756-1780}$ underwent autocleavage after incubation with a series of concentrations of InsP $\mathrm{P}_{6}$ for 4,8 , and $12 \mathrm{~h}$. Subsequently, CT26 cell lysate and intact cells were used as substrate, respectively, to check the glucosyltransferase activity of $\mathrm{TcdB}_{\Delta 1756-1780}$. The $\mathrm{TcdB}_{\Delta 1756-1780}$ efficiently induced Rac1 glucosylation using CT26 cell lysate as the substrate (Figure 3D). However, TcdB ${ }_{\Delta 1756-1780}$ failed to glucosylate Rac1 in intact CT26 cells (Figure 3C). According to the results above, we concluded that the deletion of amino acids 1756-1780 does not change the structure and function of the cysteine protease and glucosytransferase domains, but speculated that it may result in an inability to deliver GTD into the host cytosol.

Failure of cellular binding, uptake, and translocation may subsequently lead to unsuccessful toxin delivery. The cell surface binding of the mutant toxin was explored using a competition experiment. CT26 cells were incubated with $100 \mathrm{pM} \mathrm{TcdB}_{\mathrm{fl}}$ in the presence or absence of TcdB $\mathrm{B}_{\Delta 1756-1780}$ or $\mathrm{TcdB}_{\mathrm{CROP}}$ (the RBD of TcdB, AA 1852-2366) for $2 \mathrm{~h}$. As observed microscopically (Figure 3E), a 
2500-fold concentration of $\mathrm{TcdB}_{\Delta 1756-1780}$ competitively inhibited the toxic effect of $\mathrm{TcdB}_{\mathrm{fl}}$ at a similar level to 5000 -fold $\mathrm{TcdB}_{\mathrm{CROP}}$. It seemed that the competitive ability of $\mathrm{TcdB}_{\triangle 1756-1780}$ was two-fold stronger than that of $\mathrm{TcdB}_{\mathrm{CROP}}$, which is perhaps due to the existence of a second CROP-independent receptor-binding site and the deletion of region 1756-1780 does not change the binding ability of

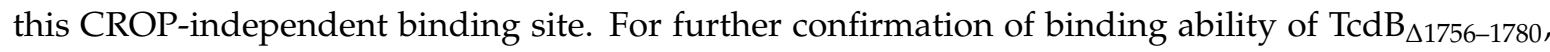
CT26 cells were incubated with FITC labeled toxins on ice and imaged by fluorescence microscopy. As shown in Figure $3 \mathrm{~F}, \mathrm{TcdB}_{\mathrm{fl}}, \mathrm{TcdB}_{\Delta 1756-1780}$, and $\mathrm{TcdB}_{\Delta 1827-1851}$ were able to bind to the surface of CT26 cells. These results demonstrated that $\mathrm{TcdB}_{\Delta 1756-1780}$ maintains approximately the same cellular binding activity as full length TcdB.
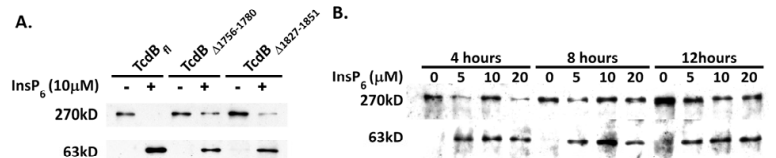

c.
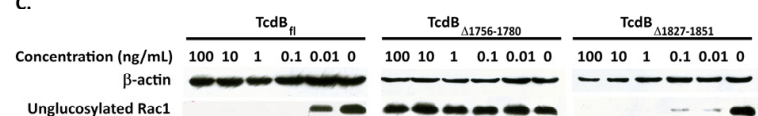

Rac1

E.

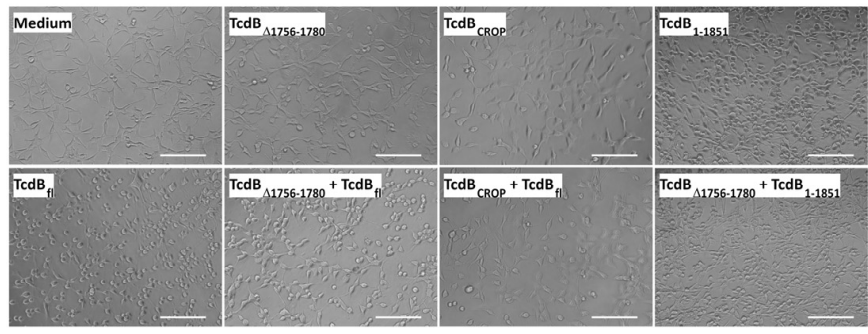

D.

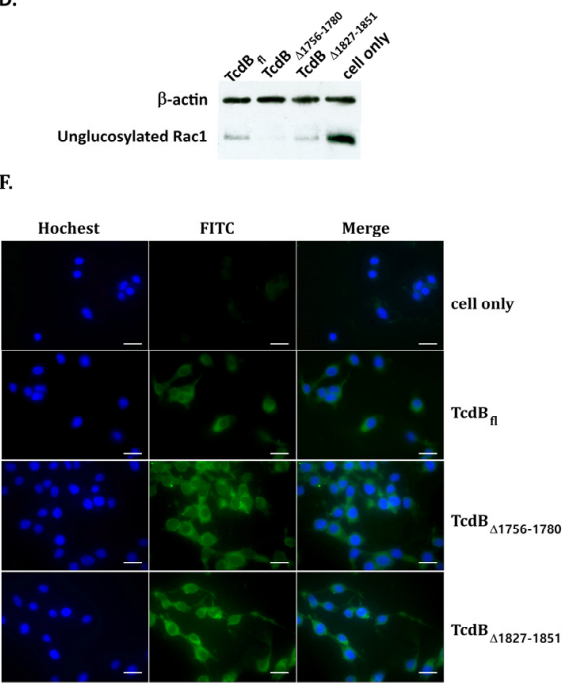

Figure 3. Glucosyltransferase and cysteine protease activities, cellular binding of $\mathrm{TcdB}_{\mathrm{fl}}, \mathrm{TcdB}_{\Delta 1756-1780 \text {, }}$ and $\mathrm{TcdB}_{\triangle 1827-1851}$. (A,B). InsP ${ }_{6}$-dependent autocleavage assay. The three toxins were incubated with $10 \mu \mathrm{M}$ InsP $\mathrm{P}_{6}$ for $4 \mathrm{~h}(\mathrm{~A})$ and $\mathrm{TcdB}_{\Delta 1756-1780}$ was incubated with a series of concentrations of 5,10 ,

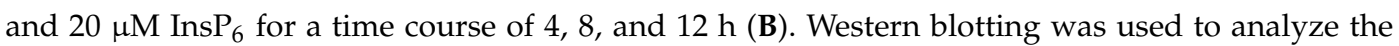
autocleavage of toxins using anti-TcdB $\mathrm{GTD}_{\mathrm{G}}$ antiserum. (C) Intact CT26 cells were exposed to a series of concentrations of $0.01,0.1,1.0,10,100 \mathrm{ng} / \mathrm{mL} \mathrm{TcdB}_{\mathrm{fl}}, \mathrm{TcdB}_{\Delta 1756-1780}$, and $\mathrm{TcdB}_{\Delta 1827-1851}$ respectively for $4 \mathrm{~h}$ before western blot analysis using anti-unglucosylated Rac1 monoclonal antibody. $\beta$-actin was used as an equal loading control. (D) CT26 cells were lysed and then centrifuged. The supernatant

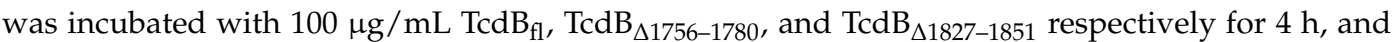
the samples were analyzed by western blot. (E) Competition experiments. Microscopic images of $\mathrm{CT} 26$ cells that were treated for $2 \mathrm{~h}$ at $37^{\circ} \mathrm{C}$ with $\operatorname{TcdB}_{\mathrm{fl}}(100 \mathrm{pM}), \operatorname{TcdB}_{\Delta 1756-1780}(250 \mathrm{nM}), \mathrm{TcdB}_{\mathrm{CROP}}$ $(500 \mathrm{nM})$, respectively, and treated for $4 \mathrm{~h}$ with $\operatorname{TcdB}_{1-1851}(0.5 \mathrm{nM})$, or with $\operatorname{TcdB}_{\mathrm{fl}}(100 \mathrm{pM}) / \mathrm{TcdB}_{1-1851}$ $(0.5 \mathrm{nM})$ together with either $\operatorname{TcdB}_{\Delta 1756-1780}(250 \mathrm{nM})$ or $\operatorname{TcdB}_{\mathrm{CROP}}(500 \mathrm{nM})$. Scale bar $=100 \mu \mathrm{m}$. (F) CT26 cells grown on coverslips were fixed with $4 \%$ paraformaldehyde and then incubated with $50 \mu \mathrm{g}$ of FITC-labeled toxins (FITC-TcdB ${ }_{\mathrm{fl}}$ FITC-TcdB $_{\Delta 1756-1780}$ and FITC-TcdB ${ }_{\Delta 1827-1851}$ ) respectively for $30 \mathrm{~min}$ at $4{ }^{\circ} \mathrm{C}$, before the cells were washed with PBS. The cells were imaged by fluorescence microscopy. Scale bar $=25 \mu \mathrm{m}$.

\subsection{Conformational Change at Low $\mathrm{pH}$ and Pore Formation by $T c d B_{\Delta 1756-1780}$}

$\mathrm{pH}$-induced changes in toxin hydrophobicity were identified by the TNS assay, which is a convenient probe for determining the exposure of hydrophobic domains under various conditions. As shown in Figure $4 \mathrm{~A}$, both $\mathrm{TcdB}_{\mathrm{fl}}$ and $\mathrm{TcdB}_{\Delta 1756-1780}$ exhibited a dramatic increase in TNS-associated fluorescence at $\mathrm{pH} 4.0$. Additionally, when the buffer was neutralized by $1 \mathrm{M} \mathrm{NaOH}$, the fluorescence of both toxins decreased (Figure 4B-D). 


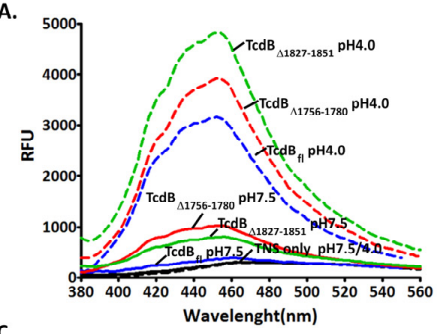

c.

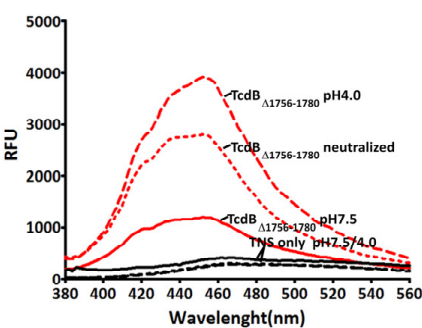

B.

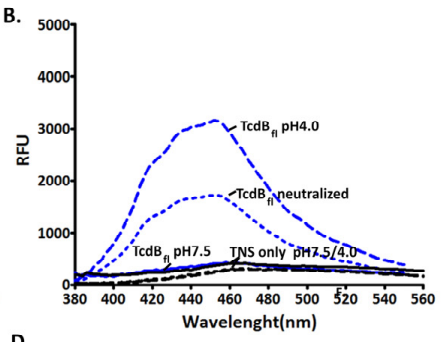

D.

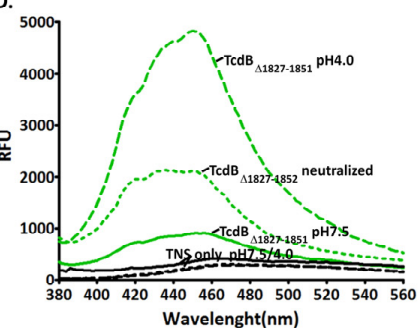

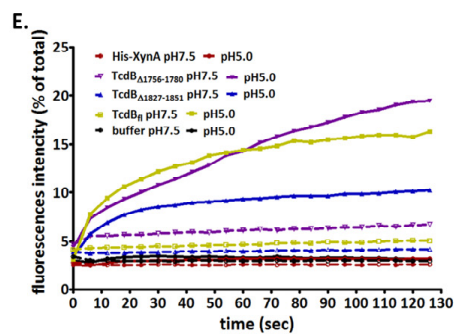

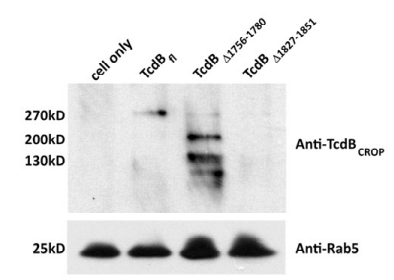

Figure 4. Conformational changes, pore formation, and behavior of the toxins in endosomes. (A-D) Conformational changes of the toxins under low $\mathrm{pH}$ using TNS fluorescence assay. $1 \mu \mathrm{g}$ of $\mathrm{TcdB}_{\mathrm{fl}}, \mathrm{TcdB}_{\Delta 1756-1780}$, and $\mathrm{TcdB}_{\Delta 1827-1851}$ were diluted in $150 \mu \mathrm{M}$ TNS solution at $\mathrm{pH} 4.0$ or $\mathrm{pH} 7.5$ (A). In the neutralization experiment, $8 \mu \mathrm{L}$ of $1 \mathrm{M} \mathrm{NaOH}$ solution was added to $1 \mu \mathrm{g}$ of $\mathrm{TcdB}_{\mathrm{fl}}(\mathbf{B})$, $\mathrm{TcdB}_{\Delta 1756-1780}(\mathrm{C})$, and $\mathrm{TcdB}_{\Delta 1827-1851}$ (D) reaction mixtures ( $\left.\mathrm{pH} 4.0\right)$ to assess refolding of the toxins. The increase of fluorescence induced by the binding of TNS to the hydrophobic region of the toxins was measured by SpectraMax M5. E. Pore formation by toxins in HPTS/DPX loaded LUVs. The pore formation was induced by acidic conditions. The fluorescence intensity was monitored on a SpectraMax M5 (Molecular Devices, Sunnyvale, CA, USA) with an excitation of $454 \mathrm{~nm}$ and an emission of $520 \mathrm{~nm}$. Total HPTS fluorescence was determined by addition of Triton X-100 (to 0.3\%), and His-XynA was used as the negative control. F. Endosome isolation and anti-TcdB western blot. $\mathrm{CHO}$ cells were exposed to $2 \mu \mathrm{g} / \mathrm{mL}$ of toxins at $37^{\circ} \mathrm{C}$ for $2 \mathrm{~h}$ before harvesting. The endosome compartments were isolated by immunoadsorption using anti-Rab5 monoclonal antibody. Subsequently, the isolated endosomes were analyzed by western blot using anti-TcdB $\mathrm{CROP}$ antisera.

Exposure of the hydrophobic region of the toxins enabled membrane insertion, which is paralleled by pore formation, resulting in the entrance of toxins into host cells directly through the endosomal membrane. The pore formation of $\mathrm{TcdB}_{\Delta 1756-1780}$ was studied by assay of fluorophore leakage from HPTS/DPX loaded LUVs. Pore formation was monitored by the release of the fluorescent dye HPTS, which is quenched in the lipid vesicles by DPX. The HPTS/DPX compounds were released and diluted when pores formed in the LUVs, which caused an increase in fluorescence by reduction of collision quenching. As shown in Figure $4 \mathrm{E}$, under low $\mathrm{pH}$ conditions, $\mathrm{TcdB}_{\mathrm{fl}}$ and $\mathrm{TcdB}_{\Delta 1756-1780}$ induced pore formation in LUVs and caused an increase in fluorescence. However, no increase in the fluorescent signal was observed under acidic $\mathrm{pH}$ with protein $\mathrm{His}_{6}-\mathrm{XynA}$, which was used as a negative control. Comparing $\mathrm{TcdB}_{\Delta 1756-1780}$ with $\mathrm{TcdB}_{\mathrm{fl}}$, the fluorescence of $\mathrm{TcdB}_{\mathrm{fl}}$ increased slightly faster than that of $\mathrm{TcdB}_{\Delta 1756-1780}$, but this may not be significant because they displayed a similar pattern of increase in general (Figure $4 \mathrm{E}$ ). From all these results, we concluded that the mutant toxin TcdB $\Delta 1756-1780$ induced conformational change and pore formation under acidic $\mathrm{pH}$ conditions in a similar pattern to TcdB $\mathrm{B}_{\mathrm{fl}}$. However, there is insufficient information about the exact mechanism by which these processes take place. We speculated that the deletion of region 1756-1780 led to locking of the TcdB in endosomes, resulting in a failure to deliver GTD.

\subsection{Behavior in Endosomes}

Endosome isolation was performed and western blot analysis was used to obtain further insight into the behavior of the toxins in endosomes. Rab5 is a regulatory guanosine triphosphatase that has been localized to the plasma membrane, clathrin-coated vesicles, and early endosomes. It participates 
in endosomal membrane fusion reactions and is important in control of endocytic function [24,25]. Rab5 is often used as an early endosome marker [24]. In this study, endosome populations were purified by immunoadsorption from syringe-lysed cell lysate using an antibody against Rab5 protein and were analyzed by western blot using anti-TcdB antibodies. The result showed (Figure $4 \mathrm{~F}$ ) that holotoxin of $\mathrm{TcdB}_{\mathrm{fl}}$ and $\mathrm{TcdB}_{\triangle 1827-1851}$ can be recognized by anti-TcdB $\mathrm{B}_{\mathrm{CROP}}$ antibody, which is specific for the receptor binding domain of $\mathrm{TcdB}$, but the band of $\mathrm{TcdB}_{\triangle 1827-1851}$ was much weaker than that of $\mathrm{TcdB}_{\mathrm{fl}}$. In contrast, a very small amount the holotoxin of $\mathrm{TcdB}_{\Delta 1756-1780}$ was detected as well as several bands of lower molecular weight. Based on these results, we hypothesize that the majority of $\mathrm{TcdB}_{\triangle 1756-1780}$ is rapidly degraded in the endosome, which prevents efficient delivery of GTD into the cytosol. Therefore, a much higher concentration of $\mathrm{TcdB}_{\Delta 1756-1780}$ would be needed to induce the same level of cell rounding or cell death when compared with wild type TcdB.

\section{Discussion}

The goal of this study is to identify the critical part of D97 segment and provide insight into the structure-function relationship of the TcdB translocation action. Over decades, efforts have been made to reveal the mechanism of delivery of the cytotoxic glucosyltransferase domain across the endosomal membrane into cytosol. Despite significant advances, there is still a long way to completely reveal the underlying mechanism of the toxin delivery. In 2013, we found that a 97-amino-acid segment (D97) located in the $C$-terminus of the translocation domain is essential for the toxicity of TcdB, and the D97 segment was hypothesized to be involved in the translocation of TcdB because TcdB-D97 failed to release GTD into the host cytosol [23]. In this study, we narrowed down the critical region of D97 and tried to investigate the function of this region. Using algorithms GOR4, SIMPA96, and Chou-Fasman (ProtScal), the secondary structure of D97 segment was predicted, demonstrating that the region covering AA 1756-1780 formed an alpha helical structure and it was hypothesized to be important. Therefore, a $T c d B$ deletion mutant $\operatorname{TcdB}_{\Delta 1756-1780}$ was constructed, while $\mathrm{TcdB}_{\Delta 1827-1851}$ was used as a control protein. $\mathrm{TcdB}_{\Delta 1827-1851}$ still exhibited almost complete in vitro and in vivo toxicity when compared with $\mathrm{TcdB}_{\mathrm{fl}}$, however, toxicity of $\mathrm{TcdB}_{\Delta 1756-1780}$ had dramatically decreased by 6-7 logs. To this point, it is inferred that the region 1756-1780 plays an important role in D97, while the region 1781-1851 may not be essential for the toxicity of TcdB. To investigate the function of the region 1756-1780, the glucosyltransferase and cysteine protease activities, cellular binding, $\mathrm{pH}$-dependent conformational change and pore formation of $\mathrm{TcdB}_{\triangle 1756-1780}$ were examined. As results, $\mathrm{TcdB}_{\triangle 1756-1780}$ maintains approximately intact functions of the GTD, CPD, and RBD as $\mathrm{TcdB}_{\mathrm{fl}}$. However, $\mathrm{TcdB}_{\Delta 1756-1780}$ was able to induce Rac1 glucosylation only when cell lysate was used as the substrate but failed when using intact cells as substrate. It is hypothesized that the deletion of 25AA 1756-1780 impairs the function of the TD. Previous studies showed that the translocation process of $C$. difficile $\mathrm{TcdB}$ is associated with $\mathrm{pH}$-induced conformational change and pore formation. Therefore, $\mathrm{pH}$-induced conformational change and pore formation were studied by TNS fluorescence analysis and the LUVs fluorophore leakage assay respectively. The results indicated that $\mathrm{TcdB}_{\Delta 1756-1780}$ had a similar pattern of conformation change and pore formation to $\mathrm{TcdB}_{\mathrm{fl}}$ under acidic conditions, which would suggest similar function in endosomes. According to our previous report, TcdB-D97 was concluded to be trapped in endosomes. Therefore, we investigated the differences between $\mathrm{TcdB}_{\mathrm{fl}}$ and $\mathrm{TcdB}_{\Delta 1756-1780}$ related to the behavior in endosomes. We found that $\mathrm{TcdB}_{\Delta 1756-1780}$ was degraded rapidly in endosomes into several fragments with different molecular weights. It is important to note that the region 1756-1780 is only a small part within the translocation domain, the deletion of which may not influence the general trend of conformational change, that is why $\mathrm{TcdB}_{\Delta 1756-1780}$ displayed conformational change in similar pattern as $\mathrm{TcdB}_{\mathrm{fl}}$ in the TNS fluorescence analysis. Nevertheless, the region 1756-1780 may be essential for a critical step in conformational change, and its deletion led to unsuccessful membrane insertion and eventually prevented GTD from being translocated across the endosomal membrane.

Recently, Björn Schorch et al. [14] proposed a two-receptor model for the cell entry of clostridial glycosylating toxins, in which the CROP domain primarily facilitates the accumulation of the toxins at the cell surface, and the additional receptor-binding domain interacts with another specific cell 
surface protein to induce the endocytosis of the toxins. A new model of the modular composition of TcdB presented by Selda Genisyuerek et al. [16] suggests that the region between AA 1500 and 1851 is not necessary for translocation and may represent an additional receptor-binding site, as deletion of the region reduced toxicity, but did not complete abrogate it. $\mathrm{TcdB}_{\Delta 1756-1780}$ was detected in the endosome, which indicates that it is able to induce endocytosis. Therefore, we suggest that the region 1756-1780 is not necessary for cellular binding but is necessary for efficient GTD translocation. Because of ineffective translocation, after endocytosis, $\mathrm{TcdB}_{\Delta 1756-1780}$ was trapped in the endosome and was subsequently degraded into small fragments. The majority of the intact GTD was therefore unable to be translocated into the host cytosol. As a result, a much higher concentration of $\mathrm{TcdB}_{\Delta 1756-1780}$ would be needed to trigger same level of cell rounding or cell death as for $\mathrm{TcdB}_{\mathrm{fl}}$.

In summary, we identified a region, 25AA 1756-1780, within D97 that is essential for TcdB toxicity. The region 1756-1780 plays a pivotal role in the translocation of GTD across the endosomal membrane, however, it is not necessary for pore formation and cellular binding. We hypothesize that the region 1756-1780 has a critical role in $\mathrm{pH}$-induced conformational change, and its deletion may lead to an incorrect conformational change, triggering steric hindrance, consequently resulting in unsuccessful membrane insertion and GTD delivery. Eventually, deletion of region 1756-1780 leads to toxin trapped and degraded in the endosome compartment (Figure 5). Determination of the crystal structure and further study of the translocation domain are needed to explain the function of the 1756-1780 region and to clarify the mechanism of action involved in TcdB translocation.

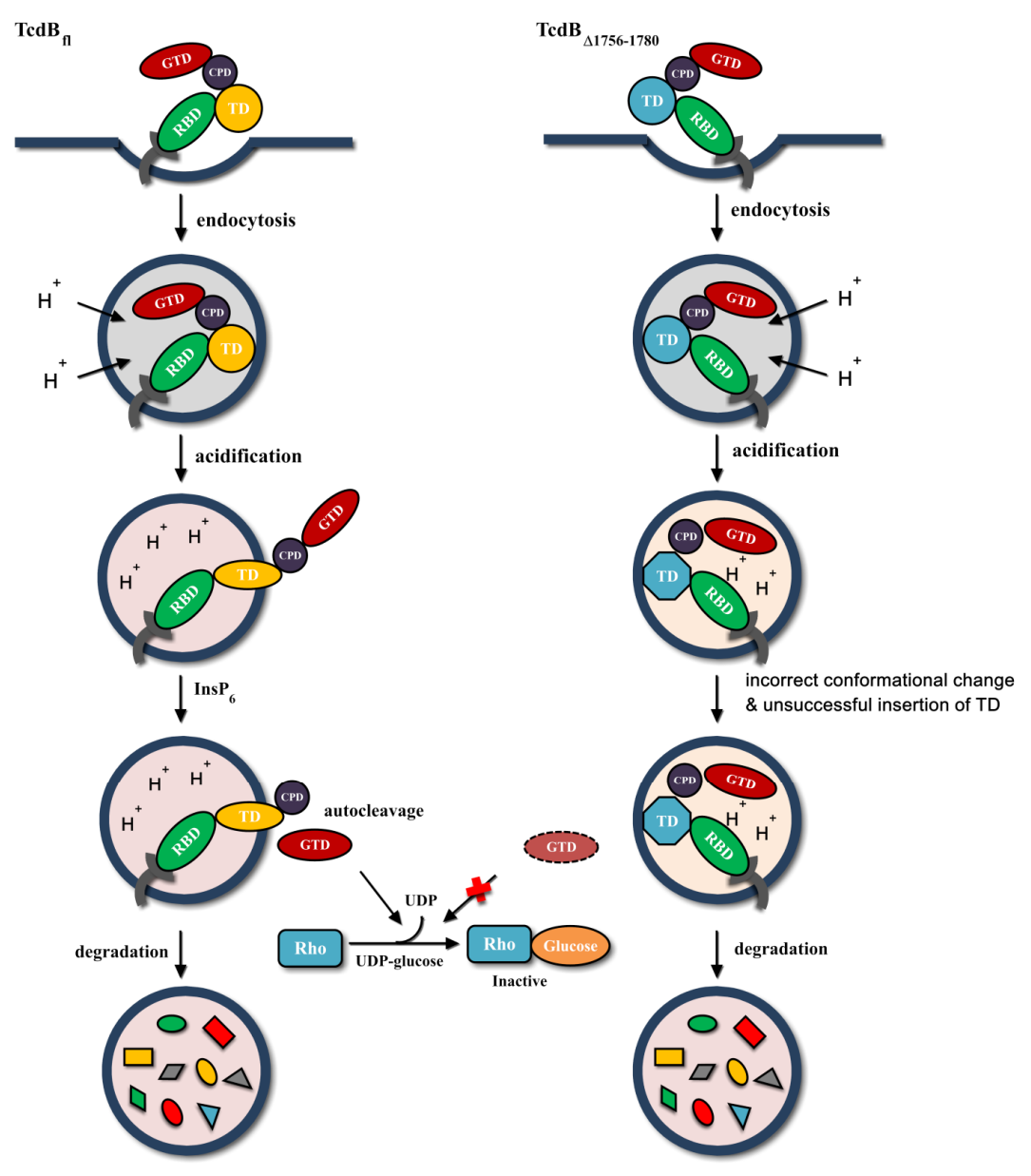

Figure 5. Scheme of $\mathrm{TcdB}_{\mathrm{fl}}$ and $\mathrm{TcdB}_{\Delta 1756-1780}$ actions of cellular uptake and GTD delivery. Compared to $\mathrm{TcdB}_{\mathrm{fl}}, \mathrm{TcdB}_{\Delta 1756-1780}$ proceeds incorrect conformational change and triggers steric hindrance after acidification of endosomes, resulting in unsuccessful membrane insertion and GTD delivery, which eventually leads to toxin trapped and degraded in the endosome compartments. 


\section{Materials and Methods}

\subsection{Mammalian Cell Lines}

CT26 cells (BALB/C mouse colon tumor cells), Vero cells (kidney epithelial cells from African green monkeys), and CHO cells (Chinese hamster ovary cells), purchased from the Chinese Academy of Sciences Institute of Cell Resource Center, were cultured in Dulbecco's minimum Eagle's medium supplemented with $10 \%$ fetal bovine serum, 100 units $/ \mathrm{mL}$ penicillin, and $100 \mu \mathrm{g} / \mathrm{mL}$ streptomycin in $100 \mathrm{~mm}$ culture plates at $37^{\circ} \mathrm{C}$ and $5 \% \mathrm{CO}_{2}$.

\subsection{Bacteria Strains}

Bacullus megaterium WH320 (MoBiTec, Goettingen, Germany) and Escherichia coli DH5 $\alpha$ (Takara, Kyoto, Japan) were cultured in LB medium at $37^{\circ} \mathrm{C}$ unless otherwise indicated.

\subsection{Cloning of $T c d B$ Constructs}

DNA corresponding to the TcdB fragments (amino acids 1-1755, 1-1826, 1-1851, 1781-2366, and 1852-2366) was amplified from cDNA encoding to full length TcdB by PCR. Subsequently, TcdB constructs with internal deletions $\left(\mathrm{TcdB}_{\Delta 1756-1780}\right.$ and $\left.\mathrm{TcdB}_{\triangle 1827-1851}\right)$ were generated by overlap PCR using the PCR products of TcdB sequences encoding amino acids 1-1755 and 1781-2366, and 1-1826 and 1852-2366 as templates, respectively. The overlap PCR products and the fragments 1-1851 were cloned into the pHis1525 (MoBiTec, Goettingen, Germany) vector using the restriction sites BsrGI and KpnI.

\subsection{Protein Expression and Purification}

The transformation of B. megaterium protoplast was performed according to the manufacturer's instructions (MoBiTec, Goettingen, Germany). The transformed B. megaterium colonies were transferred to the LB broth medium containing $10 \mu \mathrm{g} / \mathrm{mL}$ tetracycline and incubated overnight at $37^{\circ} \mathrm{C}$ with $250 \mathrm{rpm}$. The overnight culture was diluted 1:100 in LB broth medium containing tetracycline and grown to an optical density $\mathrm{OD}_{600}$ around 0.3 before the addition of xylose $(5 \mathrm{mg} / \mathrm{mL})$ to induce protein expression.

All proteins were expressed with $C$-terminal $\mathrm{His}_{6}$ tags. The purification of His-tag proteins was performed by $\mathrm{Ni}^{2+}$ affinity chromatography. Briefly, the B. megaterium pellet was suspended in $5 \mathrm{~mL}$ lysis buffer (20 mM phosphate sodium buffer, $500 \mathrm{mM} \mathrm{NaCl}, 30 \mathrm{mM}$ imidazole, pH 7.4) per $100 \mathrm{~mL}$ bacterial culture. Cells were disrupted by sonication and the lysate was centrifuged at $15,500 \times g$ for $30 \mathrm{~min}$ at $4{ }^{\circ} \mathrm{C}$. The supernatant was applied to a nickel-charged HisTrap HP column (GE Healthcare Bio-Sciences, Pittsburgh, PA, USA) and the bound protein was eluted using elution buffer (20 mM phosphate buffer, $500 \mathrm{mM} \mathrm{NaCl}, 500 \mathrm{mM}$ imidazole, $\mathrm{pH}$ 7.4). The proteins were dialyzed to PBS buffer containing $20 \%$ glycerol and stored at $-80{ }^{\circ} \mathrm{C}$.

Circular dichroism (CD) spectrophotometry was performed using a Chirascan Circular Dichroism Spectropolarimeter (Applied Photophysis Limited, Surrey, UK), with a scan interval of $1 \mathrm{~nm}$ and path length of $0.1 \mathrm{~cm}$ at $25^{\circ} \mathrm{C}$. The CD data were analyzed on the basis of the CONTIN algorithm.

\subsection{Cytotoxic and Cytopathic Effects}

The cytotoxic effect induced by the toxins was analyzed by MTT (Methylthiazolyldiphenyltetrazolium bromide) viability assay as described previously [26]. Briefly, $2 \times 10^{4}$ CT26 cells were seeded in a 96-well plate and cultured at $37^{\circ} \mathrm{C}$ for $24 \mathrm{~h}$. Serial dilutions of each toxin were added to the cells and incubated at $37^{\circ} \mathrm{C}$ for another $72 \mathrm{~h}$. Following this, $10 \mu \mathrm{L}$ of MTT was added and the plate was further incubated at $37^{\circ} \mathrm{C}$ for $2 \mathrm{~h}$. The formazan was solubilized with DMSO, and absorbance at $570 \mathrm{~nm}$ was measured using a SpectraMax M5 (Molecular Devices, Sunnyvale, CA, USA). Cell viability was expressed as a percentage of the cell survival in the control wells. 
The cytopathic effect was measured by a cell rounding experiment. CT26 or Vero cells were

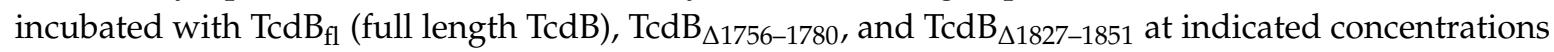
for $24 \mathrm{~h}$ and cell rounding was observed by light microscopy. The experiments were repeated three times, and triplicate wells were assessed for the MTT assay and cell rounding in each experiment.

\subsection{Mouse Systemic Toxin Challenge}

6- to 8-week-old BALB/C mice (SPF) were purchased from Guangdong Medical Laboratory Animal Center (Guangdong, China). Groups of mice $(n=6)$ were challenged intraperitoneally with $\mathrm{TcdB}_{\mathrm{fl}}(100 \mathrm{ng} / \mathrm{mouse}), \mathrm{TcdB}_{\Delta 1756-1780}(100 \mu \mathrm{g} / \mathrm{mouse})$, and $\mathrm{TcdB}_{\Delta 1827-1851}$ (100 ng/mouse), respectively. Mouse survival was monitored every six hours. The animal protocols used in this work were approved by Guangdong Provincial Department of Science and Technology (Approval Number: SYXK (Yue) 2014-0145). This research does not violate any national guidelines and institutional policies for use of animal in research.

\subsection{In Vitro Autocleavage Assay}

The in vitro autocleavage assay was performed as described previously [6,27]. Each toxin protein was diluted in $20 \mathrm{mM}$ Tris buffer ( $\mathrm{pH}$ 7.4) in a final volume of $100 \mu \mathrm{L}$. Cleavage was initiated by addition of $10 \mu \mathrm{M}$ inositol hexakisphosphate ( $\mathrm{InsP}_{6}$ ) (Sigma, St. Louis, MO, USA) and the mixture was incubated at $37^{\circ} \mathrm{C}$ for $12 \mathrm{~h}$. To investigate the dependence of the effect on the time course and the concentration of $\operatorname{InsP}_{6}$, the toxins were incubated with 5, 10, and $20 \mu \mathrm{M} \mathrm{InsP}{ }_{6}$ for 4, 8, and $12 \mathrm{~h}$, respectively. The reaction was stopped by SDS-PAGE sample loading buffer, and analyzed by western blot using anti-TcdB $\mathrm{GTD}_{\mathrm{GT}}$ (the GTD of TcdB, amino acids 1-543) antiserum prepared by our laboratory.

\subsection{In Vitro Glucosylation Assay}

The in vitro glucosylation assay was performed with intact CT26 cells and cell lysates. In the experiment with intact cells, $2 \times 10^{5} \mathrm{CT} 26$ cells were seeded in a 24-well plate and cultured at $37^{\circ} \mathrm{C}$ in $5 \% \mathrm{CO}_{2}$ for $36 \mathrm{~h}$ before being treated with different concentrations of $\mathrm{TcdB}_{\mathrm{fl}}, \mathrm{TcdB}_{\triangle 1756-1780}$, and $\mathrm{TcdB}_{\triangle 1827-1851}$ respectively for $4 \mathrm{~h}$. After treatment, the cells were washed with PBS three times, then lysed by SDS-PAGE sample loading buffer and boiled for $5 \mathrm{~min}$. In the cell lysate experiment, CT26 cell pellets were resuspended in a reaction buffer (50 mM HEPES pH 7.5, $100 \mathrm{mM} \mathrm{KCl}, 1 \mathrm{mM} \mathrm{MnCl}{ }_{2}$, and $2 \mathrm{mM} \mathrm{MgCl} 2$ ) and lysed by passing through a $30 \mathrm{G}$ needle 40 times. After centrifugation, the supernatant was used as the cytosolic fraction. For the glucosylation assay, the cytosolic fraction was incubated with $100 \mu \mathrm{g} / \mathrm{mL} \mathrm{TcdB}_{\mathrm{fl}}$ or $\mathrm{TcdB}_{\Delta 1756-1780}$ at $37^{\circ} \mathrm{C}$ for $4 \mathrm{~h}$. The reaction was terminated by adding SDS-PAGE sample loading buffer and was boiled for $5 \mathrm{~min}$. Finally, the samples were analyzed by anti-unglucosylated Rac1 mAb (BD Biosciences, San Diego, CA, USA) using western blot analysis.

\subsection{Analysis of Cell Surface Binding of the Toxins}

In the competition experiment, CT26 cells were incubated with $100 \mathrm{pM} \mathrm{TcdB} \mathrm{fl}_{\mathrm{fl}}$ for $2 \mathrm{~h}$ in the presence or absence of $250 \mathrm{nM} \mathrm{TcdB}_{\Delta 1756-1780}$, or $500 \mathrm{nM} \mathrm{TcdB} \mathrm{CROP}_{\text {(the }} \mathrm{RBD}$ of TcdB, amino acids 1852-2366). Meanwhile, CT26 cells were incubated with $0.5 \mathrm{nM} \mathrm{TcdB}_{1-1851}$ (the fragment without CROP, amino acids 1-1851) for $4 \mathrm{~h}$ with or without $250 \mathrm{nM} \mathrm{TcdB}{ }_{\Delta 1756-1780}$. Subsequently, the morphology of the CT26 cells was visualized by light microscopy.

In the immunofluorescence experiment, CT26 cells grown on coverslips to $60 \%$ confluence were fixed with $4 \%$ paraformaldehyde and subsequently incubated with $50 \mu \mathrm{g}$ of the FITC-toxins (FITC-TcdB ${ }_{\text {fl }}$, FITC-TcdB ${ }_{\Delta 1756-1780}$, and FITC-TcdB ${ }_{\Delta 1827-1851}$ ) respectively for $30 \mathrm{~min}$ at $4{ }^{\circ} \mathrm{C}$. The cells were then washed with PBS and imaged by fluorescence microscopy. 


\subsection{TNS Fluorescence Analysis of Conformational Change of Toxins}

The $\mathrm{pH}$-induced conformational change in the toxins was examined as described previously [18]. Briefly, 2-( $p$-toluidinyl) naphthalene-6-sulfonic acid, sodium salt (TNS, Sigma, St. Louis, MO, USA) was dissolved in $\mathrm{pH} 4.0$ or $\mathrm{pH} 7.5$ buffer $(100 \mathrm{mM} \mathrm{NaCl}, 100 \mathrm{mM}$ ammonium acetate, 1 mM EDTA)

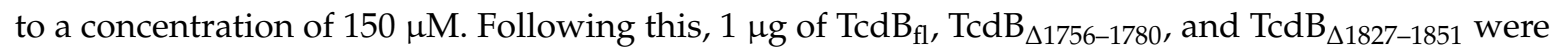
mixed into $100 \mu \mathrm{L}$ TNS solution and incubated at $37^{\circ} \mathrm{C}$ for $30 \mathrm{~min}$. In the neutralization experiment, $8 \mu \mathrm{L}$ of $1 \mathrm{M} \mathrm{NaOH}$ solution was added to the $\mathrm{pH} 4.0$ reaction mixtures to assess refolding of the toxins. The samples were analyzed by SpectraMax M5 (Molecular Devices, Sunnyvale, CA, USA) with an excitation of $366 \mathrm{~nm}$ and an emission scan of 380-500 nm.

\subsection{Fluorophore Leakage from Lipid Vesicles}

Pore formation by the toxins was measured by the fluorophore leakage from large unilamella lipid vesicles (LUVs), as previously described [16]. Briefly, the LUVs were prepared with egg phosphatidylcholine (EPC, Sigma, St. Louis, MO, USA) and cholesterol (Chol, Sigma, St. Louis, MO, USA) in a molar ratio of EPC/Chol 3:1 and 0.8\% 1,2-dioleoyl-sn-glycero-3-[( $N$-(5-amino-1carboxypentyl)iminodiacetic acid)succinyl] (nickel salt) (DGS-NTA[Ni]) (Avanti Polar Lipids, Inc., Alabaster, AL, USA). The LUVs loaded with the fluorophore mixture of 8-hydroxypyrene-1,3,6trisulphonic acid (HPTS, Sigma, St. Louis, MO, USA) and p-xylenebis( $N$-pyridinium bromide) (DPX, Sigma, St. Louis, MO, USA) were prepared according to the method described by Peschka-Süss and Schubert in 2003 [28]. In the leakage assay, the LUVs were diluted to an appropriate concentration in $20 \mathrm{mM}$ Tris buffer ( $\mathrm{pH} 7.4$ or 5.0) before toxin addition. The fluorescence of the mixture was monitored on a SpectraMax M5 (Molecular Devices, Sunnyvale, CA, USA) with an excitation of $454 \mathrm{~nm}$ and an emission of $520 \mathrm{~nm}$. Total HPTS fluorescence was determined by addition of Triton X-100 (to 0.3\%), and $\mathrm{His}_{6}-\mathrm{XynA}$ was used as a negative control.

\subsection{Endosome Isolation}

The $\mathrm{CHO}$ cells were seeded in a $100 \mathrm{~mm}$ culture dish and incubated at $37{ }^{\circ} \mathrm{C}$ for $48 \mathrm{~h}$. After exposure to $2 \mu \mathrm{g} / \mathrm{mL}$ of toxins at $37^{\circ} \mathrm{C}$ for $2 \mathrm{~h}$, the cells were scraped off in $1 \mathrm{~mL}$ PBS buffer with a plastic spreader and pelleted in a $1.5 \mathrm{~mL}$ tube $(750 \times \mathrm{g}, 2 \mathrm{~min}$ centrifugation). The cell pellet was suspended in $500 \mu \mathrm{L}$ PBS and lysed by passing through a $30 \mathrm{G}$ syringe 20-30 times until the cells were broken but the nuclei were left intact as seen by light microscopy. Subsequently, the cell lysate was centrifuged at $500 \times g$ and $4{ }^{\circ} \mathrm{C}$ for $2 \mathrm{~min}$ and the supernatant was applied to immunoadsorption against the early endosome marker Rab5.

Goat anti-rabbit IgG coated magnetic beads (Dynabeads M-280) were purchased from Invitrogen (ThermoFisher Scientific, Waltham, MA, USA). Following the manufacturer's instructions, the beads were washed with washing buffer (20 mM PBS, 0.1\% BSA, 2 mM EDTA, pH 7.4) before incubation with primary antibodies (anti-Rab5 mAb from rabbits, Abcam, Cambridge, MA, USA) at $4{ }^{\circ} \mathrm{C}$ for $12 \mathrm{~h}$. For immunoadsorption, the beads coated with primary antibody were incubated with the cell lysate at $4{ }^{\circ} \mathrm{C}$ for $12 \mathrm{~h}$. Subsequently, the beads were collected with a magnet (ThermoFisher Scientific, Waltham, MA, USA) and washed three times with washing buffer (20 mM PBS, 2 mM EDTA, 1\% BSA, pH 7.4). The samples were then analyzed by western blot.

Acknowledgments: This work was supported by grants from the Innovation Foundation for Science and Technology from the Department of Education of Guangdong Province (2013KJCX0013), Natural Science Foundation of Guangdong Province (2015A030310322) and the Guangdong Special Grant Program for High-level Talents 2013. The funders had no role in study design, data collection and interpretation, or the decision to submit the work for publication.

Author Contributions: Jufang Wang, Shuyi Chen and Haiying Wang designed the study. Shuyi Chen carried out all the experiments and wrote the paper. Huawei $\mathrm{Gu}$ and Chunli Sun provided technical assistance in protein purification and western blot analysis. Shan Li contributed to the TNS assay and Florophore leakage assay. Hanping Feng provided the TcdB cDNA and designed the mutant toxin. All authors reviewed the results and approved the final version of the manuscript. 
Conflicts of Interest: The authors declare that they have no conflicts of interest with the contents of this article.

\section{References}

1. Kelly, C.P.; LaMont, J.T. Clostridium difficile infection. Annu. Rev. Med. 1998, 49, 375-390. [CrossRef] [PubMed]

2. Kelly, C.P.; LaMont, J.T. Clostridium difficile-More difficult than ever. N. Engl. J. Med. 2008, 359, $1932-1940$. [CrossRef] [PubMed]

3. Jank, T.; Aktories, K. Structure and mode of action of clostridial glucosylating toxins: The ABCD model. Trends Microbiol. 2008, 16, 222-229. [CrossRef] [PubMed]

4. Busch, C.; Hofmann, F.; Selzer, J.; Munro, S.; Jeckel, D.; Aktories, K. A common motif of eukaryotic glycosyltransferases is essential for the enzyme activity of large clostridial cytotoxins. J. Biol. Chem. 1998, 273, 19566-19572. [CrossRef] [PubMed]

5. Jank, T.; Giesemann, T.; Aktories, K. Clostridium difficile glucosyltransferase toxin B-essential amino acids for substrate binding. J. Biol. Chem. 2007, 282, 35222-35231. [CrossRef] [PubMed]

6. Egerer, M.; Giesemann, T.; Jank, T.; Satchell, K.J.; Aktories, K. Auto-catalytic cleavage of Clostridium difficile toxins A and B depends on cysteine protease activity. J. Biol. Chem. 2007, 282, 25314-25321. [CrossRef] [PubMed]

7. Kreimeyer, I.; Euler, F.; Marckscheffel, A.; Tatge, H.; Pich, A.; Olling, A.; Schwarz, J.; Just, I.; Gerhard, R. Autoproteolytic cleavage mediates cytotoxicity of Clostridium difficile toxin A. Naunyn Schmiedebergs Arch. Pharmacol. 2011, 383, 253-262. [CrossRef] [PubMed]

8. Pruitt, R.N.; Chagot, B.; Cover, M.; Chazin, W.J.; Spiller, B.; Lacy, D.B. Structure-function analysis of inositol hexakisphosphate-induced autoprocessing in Clostridium difficile toxin A. J. Biol. Chem. 2009, 284, 21934-21940. [CrossRef] [PubMed]

9. Von Eichel-Streiber, C.; Sauerborn, M. Clostridium difficile toxin A carries a C-terminal repetitive structure homologous to the carbohydrate binding region of streptococcal glycosyltransferases. Gene 1990, 96, 107-113. [CrossRef]

10. Von Eichel-Streiber, C.; Sauerborn, M.; Kuramitsu, H.K. Evidence for a modular structure of the homologous repetitive C-terminal carbohydrate-binding sites of Clostridium difficile toxins and Streptococcus mutans glucosyltransferases. J. Bacteriol. 1992, 174, 6707-6710. [PubMed]

11. Yuan, P.; Zhang, H.; Cai, C.; Zhu, S.; Zhou, Y.; Yang, X.; He, R.; Li, C.; Guo, S.; Li, S.; et al. Chondroitin sulfate proteoglycan 4 functions as the cellular receptor for Clostridium difficile toxin B. Cell Res. 2015, 25, 157-168. [CrossRef] [PubMed]

12. LaFrance, M.E.; Farrow, M.A.; Chandrasekaran, R.; Sheng, J.; Rubin, D.H.; Lacy, D.B. Identification of an epithelial cell receptor responsible for Clostridium difficile TcdB-induced cytotoxicity. Proc. Natl. Acad. Sci. USA 2015, 112, 7073-7078. [CrossRef] [PubMed]

13. Olling, A.; Goy, S.; Hoffmann, F.; Tatge, H.; Just, I.; Gerhard, R. The repetitive oligopeptide sequences modulate cytopathic potency but are not crucial for cellular uptake of Clostridium difficile toxin A. PLoS ONE 2011, 6, e17623. [CrossRef] [PubMed]

14. Schorch, B.; Song, S.; van Diemen, F.R.; Bock, H.H.; May, P.; Herz, J.; Brummelkamp, T.R.; Papatheodorou, P.; Aktories, K. LRP1 is a receptor for Clostridium perfringens TpeL toxin indicating a two-receptor model of clostridial glycosylating toxins. Proc. Natl. Acad. Sci. USA 2014, 111, 6431-6436. [CrossRef] [PubMed]

15. Barth, H.; Pfeifer, G.; Hofmann, F.; Maier, E.; Benz, R.; Aktories, K. Low pH-induced formation of ion channels by Clostridium difficile toxin B in target cells. J. Biol. Chem. 2001, 276, 10670-10676. [CrossRef] [PubMed]

16. Genisyuerek, S.; Papatheodorou, P.; Guttenberg, G.; Schubert, R.; Benz, R.; Aktories, K. Structural determinants for membrane insertion, pore formation and translocation of Clostridium difficile toxin $\mathrm{B}$. Mol. Microbiol. 2011, 79, 1643-1654. [CrossRef] [PubMed]

17. Pfeifer, G.; Schirmer, J.; Leemhuis, J.; Busch, C.; Meyer, D.K.; Aktories, K.; Barth, H. Cellular uptake of Clostridium difficile toxin $\mathrm{B}$. Translocation of the $\mathrm{N}$-terminal catalytic domain into the cytosol of eukaryotic cells. J. Biol. Chem. 2003, 278, 44535-44541. [CrossRef] [PubMed]

18. Qa'Dan, M.; Spyres, L.M.; Ballard, J.D. pH-induced conformational changes in Clostridium difficile toxin B. Infect. Immun. 2000, 68, 2470-2474. [CrossRef] [PubMed] 
19. Ziegler, M.O.; Jank, T.; Aktories, K.; Schulz, G.E. Conformational changes and reaction of clostridial glycosylating toxins. J. Mol. Biol. 2008, 377, 1346-1356. [CrossRef] [PubMed]

20. Rupnik, M.; Pabst, S.; von Eichel-Streiber, C.; Urlaub, H.; Soling, H.D. Characterization of the cleavage site and function of resulting cleavage fragments after limited proteolysis of Clostridium difficile toxin B (TcdB) by host cells. Microbiology 2005, 151, 199-208. [CrossRef] [PubMed]

21. Giesemann, T.; Jank, T.; Gerhard, R.; Maier, E.; Just, I.; Benz, R.; Aktories, K. Cholesterol-dependent pore formation of Clostridium difficile toxin A. J. Biol. Chem. 2006, 281, 10808-10815. [CrossRef] [PubMed]

22. Zhang, Z.; Park, M.; Tam, J.; Auger, A.; Beihartz, G.L.; Lacy, D.B.; Melnyk, R.A. Translocation domain mutations affecting cellular toxicity identify the Clostridium difficile toxin B pore. Proc. Natl. Acad. Sci. USA 2014, 111, 3721-3726. [CrossRef] [PubMed]

23. Zhang, Y.; Shi, L.; Li, S.; Yang, Z.; Standley, C.; ZhuGe, R.; Savidge, T.; Wang, X.; Feng, H. A segment of 97 amino acids within the translocation domain of Clostridium difficile toxin B is essential for toxicity. PLoS ONE 2013, 8, e58634. [CrossRef] [PubMed]

24. Gilleron, J.; Zeigerer, A.; Marsico, G.; Galvez, T.; Zerial, M. Key role of Rab5: From endosome biogenesis to liver metabolism. Med. Sci. 2012, 28, 1041-1044.

25. Woodman, P.G. Biogenesis of the sorting endosome: The role of Rab5. Traffic 2000, 1, 695-701. [CrossRef] [PubMed]

26. He, X.; Sun, X.; Wang, J.; Wang, X.; Zhang, Q.; Tzipori, S.; Feng, H. Antibody-enhanced, Fc gamma receptor-mediated endocytosis of Clostridium difficile toxin A. Infect. Immun. 2009, 77, 2294-2303. [CrossRef] [PubMed]

27. Egerer, M.; Giesemann, T.; Herrmann, C.; Aktories, K. Autocatalytic processing of Clostridium difficile toxin B. Binding of inositol hexakisphosphate. J. Biol. Chem. 2009, 284, 3389-3395. [CrossRef] [PubMed]

28. Torchilin, V.; Weissig, V. Liposomes, a Practical Approach; Oxford University Press: Oxford, UK, 2003.

(C) 2016 by the authors; licensee MDPI, Basel, Switzerland. This article is an open access article distributed under the terms and conditions of the Creative Commons Attribution (CC-BY) license (http://creativecommons.org/licenses/by/4.0/). 